\title{
Co-Operative Or Coercive Federalism: The Way To Tackle The Health Emergency In India
}

\author{
Biplob Ghosh
}

\begin{abstract}
Biplob Ghosh is an assistant teacher of political science subject at Katamari High School, Cooch Behar, West Bengal and also he is a Ph.D. research scholar under Political Science Department, University of North Bengal, Siliguri, and West Bengal. His permanent residential address is, VillBhusali, P.O -Satithan, P.S - Dadpur, Dist. - Hooghly, pin- 712149.
\end{abstract}

DOI: 10.29322/IJSRP.10.10.2020.p10649

http://dx.doi.org/10.29322/IJSRP.10.10.2020.p10649

\begin{abstract}
The purpose of this paper is to analyse the role that centre-state 'co-operative federalism' has played in addressing the current 'health emergency' in a diverse federal system like India. How to play a more effective role against this pandemic, how centre-state cooperation can play an effective role in reviving the pandemic economy. How the various 'coercive' decisions of the centre have caused social problems in India. Is corona pandemic situation showing a new path to central state relations in India? Are states becoming more centralized? How much has it been possible in the last five years to restructure the rift between the centre and West Bengal in terms of 'meeting-cooperate' and negotiating relations? Why?
\end{abstract}

Index Terms- Health-emergency, co-operative federalism, coercive federalism, meeting-cooperate,

\section{INTRODUCTION}

$\mathrm{T}$ he Indian federal system is in place in the world's largest democracy, consisting of 28 states and 8 union territories. Where the power structure of the central and state is also clear. Like the union prime minister, the chief minister of the state is also accountable to the people for the past administrative work. Although the power of the central government in the Indian federal system is comparatively wider than that of the states. In fact, both the centre and states are trying their best to address the extraordinary challenges in the country. The biggest crisis in the corona start-up situation has been with the issue of hunger and migration. 'Co-operative federalism' has repeatedly dealt with crisis situation since 1970 in independence India. This is true of foreign invasions as well as of unknown pandemic

\section{II. 'CO-OPERATIVE FEDERALISM' OR 'COERCIVE FEDERALISM’ IS THE KEY FACTOR AGAINST CORONA PANDEMIC SITUATION}

Earlier this year, the global pandemic corona virus struck India (1.3 billion

Population, most of them are citizens are poor villagers), as well as the world's east-west and medically advanced countries in terms of health, socio-economic and foreign policy. The first case of corona was found in India on January 30, 2020 in Kerala.
The central government has announced a 21 days nationwide lockdown on 24 march, which was later extended to $3^{\text {rd }}$ may. In the third phase it was extended to May 17, in fourth phase it extended to May 31 and in fifth phase it extended for 7 days more nationwide lockdown up to June7.

Prime Minister Narendra Modi announced a lockdown on 25 march, 2020 to prevent this infection (to break the chain). It has ensured that people from different walks of life comply with this directive. BUT this sudden lockdown across the country has called into a question to the federal structure of India is 'co-operative' or 'coercive'. The federal system is in place in the world's largest democracy, consisting of 28 states and 8 union territories. Where the power structure of the central and state is also clear. Like the union prime minister, the chief minister of the state is also accountable to the people for the past administrative work. Although the power of the central government in the Indian federal system is comparatively wider than that of the states. In fact, both the centre and states are trying their best to address the extraordinary challenges in the country. The biggest crisis in the corona start-up situation has been with the issue of hunger and migration.

The section11 (1) of the National Disaster Management Act states that, 'there shall draw up a plan for disaster management for the whole of the country to be called the nation plan.' On the basis of which the prime minister announced a nationwide lockdown on $25^{\text {th }}$ March. But section 11(2) states that, “the national plan' shall be prepared by the national executive committee having regard to the national policy and in constitution with the state government and expert bodies or organizations in the field of disaster management to be approved by the National Authority." Although there is a 'co-operative' mentality in this part of the law, the central government has only imposed it on the central decision without discussing with state government about any form of "national plan' imposition like the announcement of this lockdown on $25^{\text {th }}$ March. At the same time it will hit the federal system of the country.

In the federal structure of India, according to the constitution, health is listed as a state subject, while infectious diseases are included in the concurrent list. But since the pandemic virus has not spread evenly across the country, it is noticeable in some states before and after another, or even in terms of magnitude. Again, the disease did not spread equally in all parts of a state or even a district. Therefore it can be expected that the state government is more knowledgeable and able to take action on public health 
issues than the central government. While the level of the virus has been declining in Kerala, on other side Maharashtra has seen an outbreak of the disease. In West Bengal's south Bengal, Kolkata, Howrah, Hooghly and North-24-Parganas etc. districts, while the number of cases of covid-19 infections is higher. While in North Bengal's Cooch Behar and Alipurdwar district the number of cases is zero. That is, states needed to be empowered to act appropriately independently on the nature and course of action against the spread of the disease and on the determination of zones. But the uniform lockdown model guideline of the central government have not been able to curb the spread of such disease on the one hand, India currently has the highest daily infection rate in the world. On the other hand, have made the economic stagnation of the states more difficult. Since the main source of income is closed, the states want to activate some economic activity in the non-containment green zones. The central government will seek to lead, allocate resources and set the right guidelines in that regard. The Indian federal system could have played a stronger role against the corona pandemic if the states had been empowered to operate independently within their constitution jurisdiction.

We can see the effort of the federalism system of the centre and state governments to take precautionary measures against Covid-19 in the state of emergency in India through the implementation of two laws. One is the Epidemic Disease Act (EDA) 1897 and another is the National Disaster Management Act (NDMA) 2005. Prior to the announcement of a nation-wide lockdown by the central government on March 25, various state government of India like Delhi, Maharashtra, Kerala, Telangana, Karnataka, Hariyana, West Bengal, Goa etc. have taken various precautionary measure to deal with the situation under section 2 of the Epidemic Disease Act 1897.

Likewise, the government ordered the closure of all types of educational institutions, public swimming pools and cinema halls till March31, which was later gradually increased.
*All hospitals should have separate concerns for screening of suspected case. In case the person has any such history of travel to affected areas in last 14 days and he/she must remain in home quarantine for 14 days from the day of exposure.

On the other hand, according to the section 2(A), central government may take measure and prescribed regulations for the inspection of any ship or vessel leaving or arriving at any port and for such detention therefor or of any person intending to sail therein or arriving thereby as may be necessary (en.wikipedia.org/wiki/Epidemic Disease Act 1897).Although this law does not mention the airports. The Home Ministry has prohibited cruise ships, crew or passengers from coronavirus-hit nations to come to India till March 31 under this Act. In addition, the government of India has issued The Epidemic Disease (Amendment) ordinance 2020 on 22.04.2020 stipulating that anyone who attack doctors and health workers is liable to seven years imprisonment. But the law does not give the government to power to deal with a biological emergency situation. The Economic Times published on 22 March 2020, reported on 'How India is fighting corona virus with a colonial-era law on epidemics' that, this may include issue that need to be addressed in order to deal with terrorist attack, biological weapons use, cross a border issues and international spread of disease (Sharma).

According to the Oxford Covid-19 Government Tracker (OXCGRT) collected data on a scale of 13 indicators such as travel bans, closure of schools, closing public transports, restriction on internal movement, testing etc.(Oxford University Launches World's first COVID-19 government response tracker), gives 'full marks' to India government for lockdown. (@BJP4India, https://twitter.com/BJP4India/status/1248649441193623554).

But over time, that is likely to change. India is currently leading the way in the daily rate of Covid-19 infection and OXCGRT gives 70-80 marks in the index. 


\section{INDIA SCORES 'FULL MARKS' FOR TAKING COMPOSITE MEASURES TO COMBAT COVID-19}

\section{COVID-19: GOVERNMENT RESPONSE STRINGENCY INDEX}

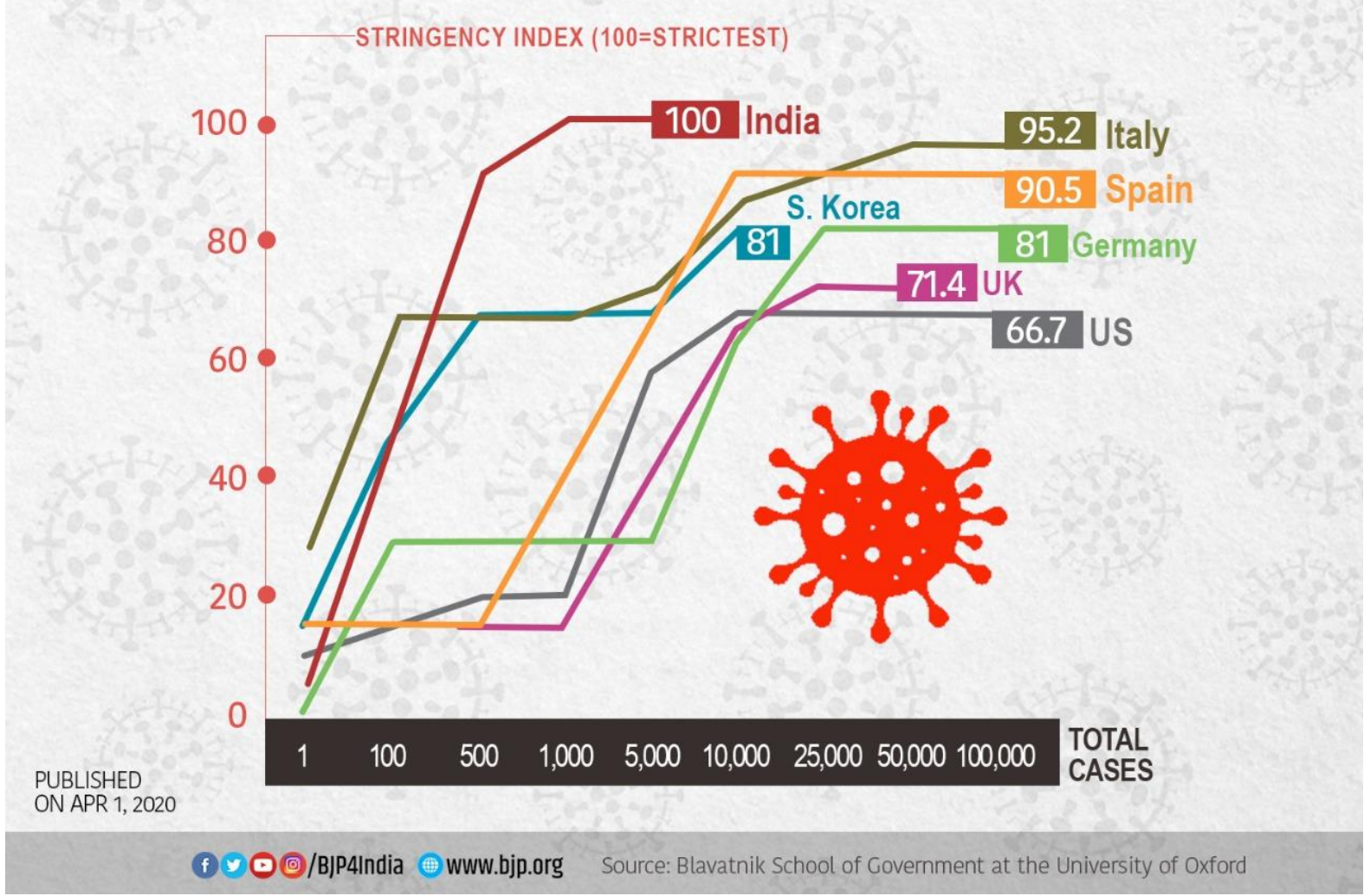


COVID-19: Government Response Stringency Index, Aug 14, 2020 This is a composite measure based on nine response indicators including school closures, workplace closures, and travel bans, rescaled to a value from 0 to $100(100=$ strictest). If policies vary at the subnational level, the index is shown as the response level of the strictest sub-region.

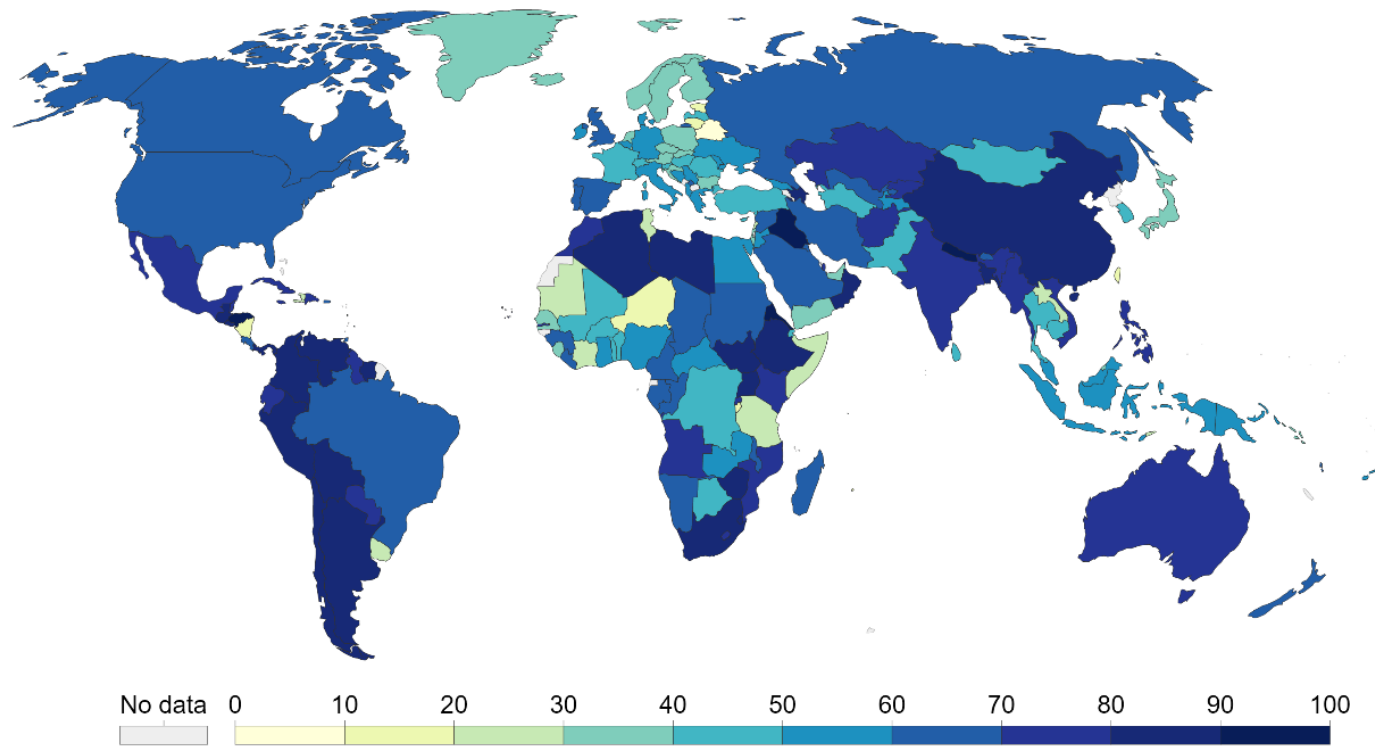

Source: Hale, Webster, Petherick, Phillips, and Kira (2020). Oxford COVID-19 Government Response Tracker - Last updated 6 September,

14:30 (London time)

Note: This index simply records the number and strictness of government policies, and should not be interpreted as 'scoring' the appropriateness or effectiveness of a country's response.

OurWorldlnData.org/coronavirus • CC BY

\section{CENTRE'S FINANCIAL BLOCKED POLICY TOWARDS STATES IN PANDEMIC SITUATION:}

Several state governments have enacted the Epidemic Act of 1897 before the centre declared a nationwide lockdown and has taken some limited action against this pandemic. On the other hand, the main source of the state have been shut down and similarly due to non-receipt of arrears of GST compensation by the states, there has been a severe financial crisis in the state. But the state governments have been working from the front to tackle this Covid19 pandemic. This means that a sufficient amount of central allocation is required for SDRMA. To this end, on March 14, MHA declared Covid19 as a 'notified disaster' and decided to allocate Rs29, 000 crore to SDRF in 2020-21 financial year. The central government allocated Rs11, 000 crore in the first phase. Although we do not see example of a neutral federal structure in this allocation. According to the Hindu newspaper published on 3 April that Maharashtra, where the highest number of infected people on Covid19, has been allocated RS1, 611 crore, while Kerala, which has the second highest number of Covid-19 cases, has been allocated RS157 crore. Again a relatively less affected state has been allocated Rs966 crore and Rs910 in Madhya Pradesh. IN Addition, Rs802 crore has been allocated to Odisha, Rs740 crore to Rajasthan, Rs708 crore to Bihar, Rs662 to Gujrat, Rs555 crore to Andhra Pradesh, Rs510crore to Tamil Nadu, Rs505 crore to West Bengal, Rs468 crore to Uttara khan, Rs308 crore to Assam, Rs247 crore to Punjab, Rs395 crore to Karnataka (Special Correspondent, Corona virus| Centre releases RS11, 092 crore under State Disaster Management Fund). It is felt that in the fight against Covid-19 pandemic, there is a need for adequate funds transfer from the central government to the states.

Although the Ministry of Corporate Affairs (MCA) on 28 March has announced that the central government's public charitable trust PM Cares Fund has given exemption from CSR expenditure under seventh schedule of the Companies Act2013. But they did not bring the Chief Minister's Relief Fund or State Relief Fund for Covid19 under this exemption. In this regard, a circular was issued by the Ministry of Corporate Affairs on 10April stating that, CM Relief fund for Covid19 would not be counted as a part of company CSR obligations. The Financial Express published on 17 April, title on 'West Bengal FM writes to Nirmala Sitaraman to allow corporate funds for Covid-19 from CSR kitty' stated that, this was demanded in a video conference of the Chief Ministers with the Prime Minister on 11 April and on 16 April the Finance Minister of West Bengal made this demand in a letter to the central government (PTI). However, the MCA circular on 23 March stated that, "spending of CSR Funds for Covid19 is eligible CSR activity" (HT Correspondent, Make donation to CM relief fund part of CSR: West Bengal FM Amit Mitra).

Secondly, the states have been repeatedly asked by the central government to pay the arrears of GST soon. Meet the GST commitment of the central government during this financial crisis will further strengthen its federal relations and structure. The Kerala government has demanded Rs3000 crore pending GST compensation from the central government as well as a $50 \%$ revenue deficit grants which is Rs15, 323 crore (PTI). In this regard Punjab's Finance Minister Manpriet Singh Badal speak that dues are pending from April to all states ... the compensation has only been received up to March 2020. 4months of dues are still 
pending. April, May, June and now July2020. 4months of pending dues is equivalent to 2 months of salary bill of all Punjab employees. In fact, all the arrears for FY19-20 have been settled by giving Rs1.65crore. But GST compensation is due from April, 2020. Since revenue short fall has worsened due to Covid19. GST collection has reduced $41 \%$ comparatively with previous year (ENS Economic Bureau, States voice concern over pending FY 21 GST dues). On the other side, According to the Business World newspaper published on 25 Aug stated that, State governments has been loss almost 6.2 lakh crore due to loss of earning from SGST, revenue from centre and additional expenditure by states government in the pandemic situation (ET Bureau).

\section{APOLITICAL APPROACH OF THE CENTRAL GOVERNMENT} TOWARDS STATES:

The central government announced 20 step on $13^{\text {th }}$ April to tackling corona virus, notable among these are-

1. An app called 'Arogya Setu' was launched to make citizens aware of the corona virus.

2. All women registered under 'Ujjwala scheme' are given free LPG refill for next three months.

3.6 Crore farmers who are registered under the 'PM-Kisan scheme' will be paid RS 6000.

4. The MGNREGA project offers daily wages of RS 202 and an additional $\mathrm{RS} 2,000$.

5. Three thousand sixty six crore rupees financial assistance has been allocated for two crore construction workers from the Building Construction Workers Fund.

6. 1400 crore are allocated for old age persons, widows and disabled peoples under the 'National Social Assistance Programme'.

7. 20 crore women 'Jan Dhan Yojana' account holders will get RS 500 for three months.

8. RS 50 lakh per person insured for health workers who do not fight pandemic.

9. 12 million metric tons of food grains are allocated for the 'Prime Ministers poor welfare scheme' for the months of April to June. (20 days, 20 step: A look at government, Hindusthan times)

According, to the latest data, more than 9.26 crore families have received gas in the prime minister 'Ujjwala Yojana' Project most of which are in Uttar Pradesh(15 million), West Bengal (78.47 lakh), Bihar (77.51lakh), Madhya Pradesh (63.31 lakh), Rajasthan (55.34lakh) . Financial Express published on 8March, on the title 'Ujjwala Scheme: UP, WB, Bihar top the list of free LPG connection scheme for poor' states that, nearly, 70,000 free gas connected are being issued in this scheme, over $40 \%$ beneficiaries are SC/ST (Krishnanand Tripathi).

According to the Economic Times published on 9April, Under the 'Pradhan Mantri Garib Kalyan' Package, 10,315 crore rupees have been credited to 20.62 crore women 'Jan Dhan' account holders by the end of April first week, as ex-gratia payment of RS. 500 would be credited for next three months. Whose maximum of account are in- Uttar Pradesh $(63,691,269)$, West Bengal (37,509,570), Madhya Pradesh (32,894,010), Rajasthan $(27,081,245)$, and Maharashtra $(27,055,642)$ (PTI). Therefore, the announcement of the payment of ex-gratia to 20.62 crore women under the central government's poor welfare scheme package states that the first-line beneficiary states, except Uttar Pradesh and Madhya Pradesh, are under the control of the opposition .

'Prime Minister's Garib Kalyan Rojgar Abhiyaan' in a situation affecting the return of migrant to India, which seek to provide livelihood opportunities to them along with other rural citizens. The Financial Express published on 20June, under the title 'Garib Kalyan Rojgar Abhiyaan highlights' that the programme lasts for 125 days, with 25 types of work that will seek to develop rural infrastructure, at least 25,000 migrant workers in a district who returned home in the states like Bihar, Uttar Pradesh, Madhya Pradesh, Rajasthan, Jharkhand and Odisha RS.50, 000 has been allocated for the development of villagers particularly to give jobs to workers (FE Online). But this scheme is not for all migrant labourers though out India or other states of India.

The Indian Express published on 8June states that among the state Uttar Pradesh has said 21.69 lakh workers had returned, Bihar has said 10 lakh, Maharashtra has said 11 lakh have left the state and Gujrat said 20.05 lakh had gone back to home (Chisti, Explained :How many migrant workers displaced ? arrange of estimates). Although in a state like West Bengal about a few lakh workers came back from outside the states, no district of West Bengal was brought under this scheme. This is depriving the interest of migrant labours of their interest which is not desirable. The state official of West Bengal said to Hindusthan Times that, about 10,000 of the 3 lakh workers who had returned have go back to the states after taking the medical certificates (Pal, Covid - free' document in hand).

The centre has agreed to spend RS. 9460 crore and the state RS 4880 crore increase fish production. Arrangements were made to pay RS. 5763 to the fisheries. It also arranges a 60:40ratio of centre-state micro Food Processing Enterprise Scheme (ET Bureau, Cabinet clears food processing Scheme). The Hindu published on 17 June shows that, Odisha government has launches door to door covid-19 survey by ASHA and Anganwadi workers. About five and a half lakh migrant workers have returned to the state (Special Correspondent, Odisha government launch door to door survey).

\section{LEGALITY OF CENTRE's INTERVENTION ON STATES}

At present, the country's authoritarian populist leader are expanding their authority by taking advantage of the health emergency situation. The Economic Times published on 4 May stated that, "It is not just the USA where president Donald Trump has tried to turn residents of certain states against their own governor, In India, the ministry of Home Affairs run by Prime Minister Narendra Modi no-2 has begun sending out ‘ investigation team ' to harass states run by the opposition, such as West Bengal " (Sharma, Corona virus is straining).Home Ministry on April 20 , said in a statement that violation of lockdown and covid-19 situation is specially serious in Mumbai, Pune, Indore, Jaipur, Kolkata and a few other places in West Bengal .Similarly , 6 IMCT teams were sent to Maharashtra ,West Bengal, Madhya Pradesh and Rajasthan for on-the spot inspection. Jayatri Nag reported to the Mumbai Mirror that, According to the Health Ministry rate was recorded in West Bengal at $9.57 \%$ where on $5^{\text {th }}$ May, the IMCT team sent to the state had said that the morality 
rate in West Bengal is $12.8 \%$, the figure stood lower in Maharashtra, where the morality rate is $3.85 \%$, higher than the national average.

West Bengal chief minister Mamata Banerjee tweeted on 20 April, 2020 that "we welcome all constructive support and suggestion especially from the central government in negotiating 'the \# covid-19 crisis "(twitter @mamata official. April20).However, In a communication between state's chief secretary and Ministry of Home affairs states that the central government has taken step to so in the greater interest of the common general public (Singh, Inter-Ministerial central teams).

\section{REFLECTION OF CENTRAL-STATE RELATION ON MIGRANT WORKERS ISSUE:}

According to the 2011 census, 45.6 crore peoples migrant to India, from $31 \%$ in 2001, of these, UP, Bihar has the highest number of migrants going to work in other states and Maharashtra and Delhi have the highest number of arrivals (Madhunika Iyer, migration in India).

Although, some protections are provided for migrant workers under the Inter-state Migrant Workmen Act 1979, employers need to be licensed and migrant workers must be registered by the government. On the other hand, these inter-state migrants do not get the benefit of PDS till they get a new card from the host state by depositing their ration card in the home state.

A nationwide lockdown due to the corona pandemic situation has prompted interest migrant workers to return to their home state. Although late From 1 may to 3 June, more than 58 lakh workers returned to home by train about 41 lakh workers by bus. On March 28 and April 29 the ministry of home affairs allowed states to spend to bring in migrant workers from the State Disaster Response Fund. The Republic World published on 30 April stated that the central government on 28 march urged the state government to utilise RS 29000 crore from SDRF to help vulnerable by providing food and shelter to migrant labours Centres Continuous Efforts to.

1 April Ministry of Health and Family Affairs instructs state to provide food and medical services for migrant workers. Subsequently, on 14 may, the Ministry of Finance directed to migrants workers and to start the One Nation One Ration scheme from March 2021. The Supreme Court in 9 June ordered; directed all states to arrange for the return of willing workers to their respective states within 15 days and to arrange for registration and skills (Times of India, Huge gaps in migrant data). Section 11(3)(b) under the Disaster Management Act 2005 stated that measures to be taken for the integration of mitigation measures in the development plans', although the development plan adopted by the government talks about integration, preparedness and capacity building among the centre and states, the government's experience in repatriating migrants labourer to their home states can be noticed.

Another thing is noticeable that, Section 11 (3) and (4) stated that 'appropriate provision shall be made by the central government for financing the measures to be carried out under the national plan'. Although the central government has announced a financial package in this regard, it has not taken effective action against the migrant workers and has only shifted the responsibility to the state government. The centre should have taken appropriate action in this regard as the financial resources of the state government were less at this time. Shraddha Sharma has speak in the 'Legal Service India' that, "In the pandemic, the state as well as central government failed to provide adequate relief to the stranded migrant workers and grossly violated their basis health and sanitation facilities to the migrant workers during the pandemic and they should be received back home in a safe and dignified manner" (Sharma, Migrant Labour Crisis in India).

\section{CENTRE-STATE MEETING-COOPERATISM IN PANDEMIC SITUATION}

Maintaining the federal pattern in this pandemic situation is an exceptional challenge and opportunity for the central government. Balveer Arora says that the states were the frontline for this combat against covid-19 to the extent that Prime Minister Modi was obliged to consult chief ministers through video conference thrice within a short span of time something that had been missing during the last six years on other issues (Arora, Centre has chosen to assert authority).

To deal with the coronavirus pandemic, the centre and all the states came together in a discussion on March 12 to work shoulder and formulate and implement 5the policy. The chief minister of West Bengal has made it clear that this is not the time to politicize and this is not the time to highlight the differences between the states and centre. At this time, the centre and state need to work together, help to people and invest in public health. He spoke to the prime minister about the more testing centre and funding so that the states can deal with this real emergency in a fair way. In fact, through this video conference, the centre and states trying to give the right direction to the states by removing the political opposition. In fact, states and centre are currently located on the same page.

The prime minister second video conference with the chief ministers of all the states focused on the issues to combat the spread of corona virus are basically, cheek the spread of corona virus, movement of migrants, availability of essential and contact tracing of Tablighi Jamaat participations are likely to come up for discussion (PTI).

On 27 April prime minister's virtual meeting with the chief ministers of various state government discussed on several issues such as lock down extension to combat further spread of covid-19, the state of economy and lifting of restriction etc. Union Home Ministry stated that around 2crore people have been given employment through the Mahatma Gandhi National Rural Employment Guarantee Act., till 27 April, 2020. (Corona virus highlights, Business Today, April27, 2020)

In the fifth meeting of the prime minister chief ministers in the corona episode situation, prime minister Narendra Modi assured the chief ministers of all states that the open up about the economy . He also said that 'government decided to invite all chief minister to speak before a considered view is taken on the matter. The prime minister speak " I request you all to share with me by $15^{\text {th }}$ May, a broad strategy on how each one of you would want to deal with the lock down regime in your particular states"( NDTV; Prime minister modi asks states for blueprint on next phase of lockdown :10 points, 12 May,2020). 
In this case we can see the cooperative federalism mentality of bringing the states of the central government together. On the other hand, the states despite their difference with the centre have conveyed a massage to the centre policy by participating in the meeting. The states of Maharashtra, Punjab, Assam and Telangana has voted in favour of the lockdown extension. However, Delhi chief minister who has repeatedly drawn attention to the loss of revenue for the city-state, said economic activity should resume in the capital, except in corona virus containment zones which are in strict lock down to check the spread of the virus" (Sharma and Prabhu, Prime minister Modi asks states for blue print on next phase of lock down; 10 points). Agreeing with this, the chief minister of Kerala demanded that the states be given the power to determine the boundaries of the lock down. He also said " the states face different challenges and therefore should be given the freedom to make reasonable changes to the guidelines relating to the lock down(Sharma and Prabhu, Prime minister Modi askes states for blue print on next phase of lockdown;10 points). Haryana chief minister Monohar Lal Khattar has similarly called for the introduction of economic activities in the state. Originally, West Bengal chief minister Mamata Banerjee said that the central government should give equal status to all the state so that Team India could work together in this situation. She said," this is not the time to play politics. Nobody ever asks our opinion...... don't bulldoze the federal structure "(Relaxing lockdown restarting economy what the prime minister and chief ministers said, THE QUINT).

In the minds of migrant workers in the speeches of all states, prime minister in his opening remarks, Prime Minister Modi spoke about migrants, starting that he understands their need to go home. From May 11, limited special trains will run between Delhi and 14 states. Prime minister thanks to all chief minister for proactive role against covid-19 and their grass root level experience (FP Staff, Coronavirus out break up dates). The chief minister of Chhattisgarh demanded RS. 30,000 crore for implementing relief and welfare schemes and separate power of the states for determining green, orange and red zones.

In a large populous country like India, the death toll was 673,904 as on 05.07 .2020 , but the death toll was $2.86 \%$, which is relatively low. In fact, the challenge for the government is to address the issue of coordination between ' live and livelihood', 'current need and future requirement'. On the first day of the sixth virtual conference of the prime minister with the chief ministers of the states of Punjab, Kerala, Assam , Uttarakhand, Jharkhand, Chhattisgarh, Himachal Pradesh, Goa, Puducherry and six northeast states. The LT. Governor of Chandigarh, Andaman Nicobar Island, Dadra \& Nagar Haveli and Lakshadweep are also attended this meeting.

On the one hand, the prime minister asked the other states to follow the strategic model of the Punjab government which has successfully tackled this pandemic. Similarly, there has been a request from the states to the centre to work together to tackle the covid-19 affected economy. On the other hand, the prime minister lauded the efforts of the Uttarakhand government to build an 'Atma Nirbhar Bharat' (Shrivastava, Coronavirus crisis). The prime minister has said that ' India's fight against corona virus will be remembered in the future for how we work together and served as an example of cooperative federalism' (Saxena, India's fight against covid-19 will be remembered) .

\section{CONCLUSION}

Cooperative, flexible federalism like India has need to play an effective role in such health emergency situation. Although in many countries of the world, such as the USA, the issue was not given due importance until the president's declaration of national emergency on March 13, although it was spread across the country. The federal system did not respond properly at first, because inadequate bio-surveillance, 'there are not enough test to go around, a major problem for states as they begin to consider lifting stay at home orders and easing social distancing restriction (Gerstein, Epic Fail), Emergency management personnel in states and local area, chain for distributing information and supply has failed to play an effective role in tackling this crisis. Although the states of India were able to take independent action in the first phase of the covid-19, like lockdown announcement, schools and others educational institutions, cinema halls, swimming polls etc. closing. But the central government later started misusing the NDMA act on the states especially the non-BJP ruled states. Where it is stated in section 11(1) and (2) of the NDMA act that, to draw up a national plan for the whole country with consultation with state government. But the central government suddenly announced a nationwide lockdown on 25 March without any prior consent and planning with the state governments, which triggered a food crisis, unemployment and a plight of migrant workers across the country. Which was originally issued without consulting the states in dealing with the covid-19 situation, similar to the demonetization, CAA. In that case, the states did not have time to repatriate migrant workers or provide adequate resources for them. So that the life of migrant labourers ended in street death. In a country where $85 \%$ of the total workers are employed in the informal sector, who are contribute $50 \%$ to the national income of the country, economic protection should have been provided by the central government and the states.

The first step in this regard was taken by the chief minister of West Bengal, who on March26 informed the eighteen state government to rescue the migrants and to take cooperative steps. Maharashtra government announced 480 million package, Kerala government builds relief camp shelter. The important role of the central government is to lead in the right direction, to provide financial assistance as well as to increase the revenue of the states, employment, health, law and order.

While the announcement of a lockdown against covid-19 was initially easy, the uniform and rigid approach of the centre in the Indian federal system is not desirable. In the crisis situation, it is important to reconcile the two units of the federation and civil society, although this has not been largely effective.

In fact, the central control of the traditional federal system and the enigma of more states autonomous has been developed in India on the principle of cooperative federalism based on its own policy, we hope that India is active in overcoming the pandemic situation through cooperative relations. However, this crisis has largely suppressed the extreme conflict in India over the centre a few month ago. It is our hope that the level of development of the country will reach all the people at the same rate and similarly, the central government will harmonize the activism and demands of the states in this regard. 


\section{REFERENCES}

[1] Sharma, Shantanu, Nandan. "How India is fighting corona virus with a colonial-era law on." The Economic Times, March22, 2020.

[2] https://economictimes.indiatimes.com/news/politics-and-nation/howindia-is-fightingepidemics/articleshow/74752473.cms

[3] Special Correspondent. "Corona virus| Centre releases RS11, 092 crore under State Disaster Management Fund." The Hindu, 3 April, 2020. https://www.thehindu.com/news/national/centre-releases-11092-croreunder-sdrmf/article31251774.ece\#!

[4] PTI. "West Bengal FM writes to Nirmala Sitharaman to allow corporate funds for Covid-19 from CSR kitty." Financial Express, 17April, 2020. https://www.financialexpress.com/economy/west-bengal-fm-writes-tonirmala-sitharaman-to-allow-corporate-funds-for-covid-19-from-csrkitty/1931455

[5] HT Correspondent. "Make donation to CM relief fund part of CSR: West Bengal FM Amit Mitra." Hindusthan Times. 17April, 2020. https://www.hindustantimes.com/india-news/make-donation-to-cm-relieffund-part-of-csr-west-bengal-fm-amit-mitra/story-

40y4IpLKWZoFWMaamkyiiO.html.

[6] ENS Economic Bureau." States voice concern over pending FY 21 GST dues." The Indian Express, 30 July, 2020. https://indianexpress.com/article/business/states-voice-concern-overpending-fy21-gst-dues-6529892/

[7] ANI." States share at uncovered losses of up to Rs3.1 lakh crore in FY 21: SBI report." BUSINESSWORLD, 25 Aug, 2020 http://www.businessworld.in/article/States-face-uncovered-losses-of-Rs-31-lakh-crore-in-FY21-SBI-report/24-08-2020-312425/.

[8] HT Correspondent."20 days, 20 step: A look at government's measure against covid-19 amid lockdown." Hindusthan Times, April 13, 2020. https://www.hindustantimes.com/india-news/20-days-20-steps-a-look-atgovernment-s-measures-against-covid-19-amid-lockdown/storyaUNOgQ9Om2dxQt9WAyEaGI.html .

[9] HTCorrespondent."'20 days, 20 step: A look at government's measure against covid-19 amid lockdown." Hindusthan Times, April 13, 2020. https://www.hindustantimes.com/india-news/20-days-20-steps-a-look-atgovernment-s-measures-against-covid-19-amid-lockdown/storyaUNOgQ9Om2dxQt9WAyEaGI.html.

[10] https://thebulletin.org/2020/04/epic-fail-why-the-us-wasnt-prepared-for-thecoronavirus-pandemic/

[11] Tripathi, Krishnanand. "Ujiwala Scheme: UP, WB, Bihar top the list of free LPG connection scheme for poor." Financial Express, 8 march, 2019 https://www.financialexpress.com/india-news/ujjwala-scheme-up-westbengal-bihar-top-the-list-of-free-lpg-connection-scheme-for-poor/1510053/

[12] PTI. " Centre credits RS. 500 each to over 40.07 crore women Jan Dhan account holders." The Economic Times, 09 April, 2020. https://economictimes.indiatimes.com/industry/banking/finance/banking/ce ntre-credits-rs-500-each-to-over-4-07-crore-women-jan-dhan-account holders/article show/74973340.cms?from=mdr

[13] FE Online. "Garib Kalyan Rojgar Abhiyaan highlights: Prime Minister launches mega scheme for migrant workers; states Chief Minister's present too." $\quad$ Financial Express, 20 June,2020. https://www.financialexpress.com/economy/garib-kalyan-rojgar-abhiyaanlive-pm-modi-launches-mega-scheme-for-migrant-workers/1997691/ .

[14] Chisti, Seema. "Explained: How many migrant workers displaced ? arrange of estimates." The Indian Express, 8June, 2020.https://indianexpress.com/article/explained/coronavirus-how-manymigrant-workers-displaced-a-range-of-estimates-6447840/

[15] Pal, Sreyashi. 'Covid-free' document in hand, Bengal migrant back to job in other states, Hindustan Times, 11 June, 2020. https://www.hindustantimes.com/india-news/covid-free-document-in-handbengal-migrants-back-to-jobs-in-other-states/storymlYuwEcZ4QVkNlWpGLMGIN.html.

[16] ET Bureau. "Cabinet clears food processing Scheme, fisheries package and free food grains allocation for migrants." The Economic Times, 21 May, 2020. https://economictimes.indiatimes.com/news/economy/policy/cabinet- clears-food-processing-scheme-fisheries-package-and-free-food-grainsallocation-for-migrants/articleshow/75849031.cms.

[17] Special Correspondent. "Odisha government lunches door to door survey." The Hindu, 17 June, 2020 https://www.thehindu.com/news/national/coronavirus-odisha-for-door-todoor-survey-to-detect-corona-cases/article31837344.ece\#!.

[18] Sharma, Mihir." View: Corona virus is straining the concept of federalism." The Economic Times, 04 May, 2020 https://economictimes.indiatimes.com/news/economy/policy/viewcoronavirus-is-straining-the-concept-offederalism/articleshow/75528793.cms .

[19] Nag, Jayatri. "West Bengal has highest Covid-19 morality rate, says central team." Mumbai Mirror, 4 May, 2020. https://mumbaimirror.indiatimes.com/coronavirus/news/west-bengal-hashighest-covid-19-mortality-rate-says-centralteam/articleshow/75535995.cms

[20] Sing, Shiv, Sahay. "Inter-Ministerial central teams to look into lockdown violations in West Bengal." The Hindu, 20April, 2020 https://www.thehindu.com/news/national/other-states/inter-ministerialcentral-teams-to-look-into-lockdown-violations-inbengal/article31387831.ece\#!

[21] Iyer, Madhunika. "Migration in India and the impact of the lockdown on migration." PRS LEGISLATIVE RESEARC, June10, 2020. https://www.prsindia.org/theprsblog/migration-india-and-impact-lockdownmigrants .

[22] Pavani, Sai, Deepthi. "Republic World.com; Centres Continuous Efforts to Migrant Labour amid the Lockdown." Republic World.Com, 30 April,2020.https://www.republicworld.com/india-news/generalnews/centres-continous-efforts-to-provide-relief-to-migrant-labourers-amid.

[23] Mathur, Swati. " Huge gaps in migrant data submitted by states to labour ministry says Supreme Court." Times of India, 11 June, 2020 https://timesofindia.indiatimes.com/india/huge-gaps-in-migrant-datasubmitted-by-states-to-labour-ministry-supremecourt/articleshow/76314918.cms .

[24] Sharma, Shraddha. "Migrant Labour Crisis in India." Legal Service India. http://www.legalserviceindia.com/legal/article-3587-migrant-labour-crisisin-india.html

[25] Arora, Balveer. "Centre has chosen to assert authority by micro-managing states during the covid-19 crisis." THE PRINT, April, 2020).

[26] PTI. "Prime Minister holds video conference with chief ministers on corona virus." Deccan Herald, 02April, 2020 https://www.deccanherald.com/national/pm-modi-holds-video-conferencewith-chief-ministers-on-coronavirus-820363

[27] Sharma, Akhilesh. Prabhu, Sunil. "Prime minister Modi asks states for blue print on next phase of lock down; 10 points." NDTV, 12 May, 2020. https://www.ndtv.com/india-news/coronavirus-india-lockdown-at-pmmodi-virtual-meet-today-floor-open-to-all-chief-ministers-10-points2226666 .

[28] "Relaxing lockdown restarting economy what the prime minister and chief ministers said." THE QUINT, 12 May, 2020. https://www.thequint.com/news/india/pm-modi-video-call-meeting-withchief-ministers-coronavirus-lockdown-news

[29] "Coronavirus India Highlights: Delhi-Haryana boarder to be sealed; total covid-19cases in India reach 28,380." Business Today, April27, 2020. https://www.businesstoday.in/current/economy-politics/coronavirus-indialive-updates-pm-modi-video-conference-lockdown-mumbai-delhi-cases-27apr/story/402073.html .

[30] FP Staff. "Coronavirus outbreak up dates: Narendra Modi says measure needed in 3rd phase of covid-19 lockdown are not required in 4th phase." First Post, May12, 2020. https://www.firstpost.com/health/coronavirusoutbreak-highlights-covid-19-india-pm-narendra-modi-video-conferencecm-meeting-lockdown-extension-today-death-count-cases-latest-news8353881.html.

[31] Shrivastava, Rahul. "Coronavirus crisis: PM Modi to hold two round of talks with chief ministers today, tomorrow." INDIA TODAY, 16 June, 2020. https://www.indiatoday.in/india/story/coronavirus-crisis-pm-modi-to-holdsecond-round-of-talks-with-chief-ministers-today-tomorrow-16893972020-06-16 .

[32] Saxena, Sparshita. "India's fights against covid-19 will be remembered as example of cooperative federalism': Highlights of PM Modi's meeting with 
CMs.” Hindusthan Times, 16 June, 2020. https://www.hindustantimes.com/india-news/india-s-fight-against-covid-19will-be-remembered-as-example-of-cooperative-federalism-highlights-ofpm-modi-s-meeting-with-cms/story-bV117yjutY1pN5rC8UTOCP.html .

[33] Gerstein, Daniel. M." Epic fail: Why the US was not prepare for the corona virus pandemic." Bulletin of the atomics, 24 April, 2020. https://thebulletin.org/2020/04/epic-fail-why-the-us-wasnt-prepared-for-thecoronavirus-pandemic/

\section{AUTHORS}

First Author - Biplob Ghosh, Biplob Ghosh is an assistant teacher of political science subject at Katamari High School, Cooch Behar, West Bengal and also he is a Ph.D. research scholar under Political Science Department, University of North Bengal, Siliguri, and West Bengal. His permanent residential address is, Vill- Bhusali, P.O -Satithan, P.S - Dadpur, Dist. Hooghly, pin- 712149. 